\title{
SpringerBriefs in Philosophy
}


More information about this series at http://www.springer.com/series/10082 
Charles T. Wolfe

Materialism: A HistoricoPhilosophical Introduction

囪 Springer 


\author{
Charles T. Wolfe \\ Department of Philosophy and Moral Sciences \\ Sarton Centre for History of Science \\ Ghent University \\ Ghent, Belgium
}

ISSN 2211-4548

SpringerBriefs in Philosophy

ISBN 978-3-319-24818-9

ISSN 2211-4556 (electronic)

DOI 10.1007/978-3-319-24820-2

\title{
ISBN 978-3-319-24820-2 (eBook)
}

\section{Library of Congress Control Number: 2015953229}

Springer Cham Heidelberg New York Dordrecht London

(c) Springer International Publishing Switzerland 2016

This work is subject to copyright. All rights are reserved by the Publisher, whether the whole or part of the material is concerned, specifically the rights of translation, reprinting, reuse of illustrations, recitation, broadcasting, reproduction on microfilms or in any other physical way, and transmission or information storage and retrieval, electronic adaptation, computer software, or by similar or dissimilar methodology now known or hereafter developed.

The use of general descriptive names, registered names, trademarks, service marks, etc. in this publication does not imply, even in the absence of a specific statement, that such names are exempt from the relevant protective laws and regulations and therefore free for general use.

The publisher, the authors and the editors are safe to assume that the advice and information in this book are believed to be true and accurate at the date of publication. Neither the publisher nor the authors or the editors give a warranty, express or implied, with respect to the material contained herein or for any errors or omissions that may have been made.

Printed on acid-free paper

Springer International Publishing AG Switzerland is part of Springer Science+Business Media (www. springer.com) 


\section{Acknowledgments}

The ideas and the material contained in this volume have been discussed, taken apart, and reassembled over the past 15-odd years in different venues including the Central European University, Budapest; the Jan Van Eyck Academy, Maastricht (Versus Theory Laboratory); Goldsmiths College of the University of London; Nagoya City University; Rice University, Houston; and the Universities of Groningen, Liège, Mainz, Paris 1-Panthéon-Sorbonne, Paris-Diderot, Poitiers, Stendhal-Grenoble 3, Sydney, Texas (El Paso), Toulouse-Le Mirail (in my undergraduate class on materialism), and Turin. Chapters 4, 5, and 6 contain thoroughly reworked membra disjecta from earlier publications: Anatomy and the Organization of Knowledge, 1500-1850, edited by Matthew Landers and Brian Muñoz (London: Pickering and Chatto, 2012); Mindful Aesthetics: Literature and the Science of Mind, edited by Helen Groth and Chris Danta (London: Continuum, 2014), and "Vital materialism" in the open access journal Philosophica (Ghent, 2013); their consent, including that of Taylor and Francis, is gratefully noted. An earlier version of Chap. 8 appeared as "De-ontologizing the Brain: from the fictional self to the social brain," CTheory 30:1 (Winter 2007), http://www.ctheory.net/articles. aspx?id=572, and is used here with the permission of the editors of CTheory. Readers wishing for a more detailed presentation of the eighteenth-century materialism may consult my chapter on the topic in the Routledge Companion to Eighteenth-Century Philosophy, ed. Aaron Garrett (London: Routledge, 2014).

Some of the research presented here was conducted under the auspices of funding from the Australian Research Council, the Special Research Fund (BOF) of Ghent University, and the Research Foundation of Flanders (FWO). I also warmly acknowledge discussions with friends and colleagues including Christoffer Basse Eriksen, Aaron Garrett, Alexandre Métraux, Paola Rumore, John Sutton, and John Symons; Lucy Fleet at Springer; and the retired professor in the corduroy suit who shouted at me that "Materialism will never explain the categorical imperative!" This book is dedicated to Paola, Tommaso, and Filippo. 



\section{Contents}

1 (Introduction): Materialism, Opprobrium and the History of Philosophy …………………….............................. 1

1.1 Definitional Problems........................................................................... 1

1.2 Dead Matter and the Opprobrium of Materialism................................. 6

1.3 Forms of Materialism ....................................................................... 10

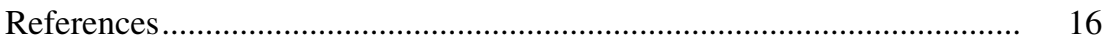

2 To Be Is to Be for the Sake of Something: Aristotle's Arguments



2.1 Introduction ......................................................................... 19

2.2 A Biologistic Metaphysics: From Form and Matter to Change and Generation .............................................................. 20

2.2.1 Why Do We Need Functional Explanations?........................ 20

2.2.2 Functionalism................................................................... 23

2.2.3 Chance........................................................................... 24

2.3 'For the Sake Of' Against Materialism ................................................ 27

2.3.1 Nature as 'For the Sake Of' '................................................. 27

2.3.2 'Matter For the Sake of X' .................................................... 28

2.4 Conclusion.............................................................................. 31

References...................................................................... 33

3 Chance, Necessity and Transformism: Brief Considerations................ 35

3.1 'Un coup de dés jamais n'abolira le hasard': Materialism, Transformism and Chance .......................................... 35

3.2 Determinism Without Laws of Nature? ............................................ 39

3.3 Conclusion.......................................................................... 40



4 Early Modern Materialism and the Flesh or, Forms of Materialist Embodiment .................................................... 43

4.1 What Is Materialist Embodiment? .................................................... 43

4.2 Is Mechanism the Problem? .............................................................. 47 
4.3 Visceral Reductionism ............................................................... 49

4.4 Vital Materialism.............................................................................. 53

4.5 Conclusion....................................................................... 55



5 Vital Materialism and the Problem of Ethics in the Radical Enlightenment ................................................................ 61

5.1 Vital Materialism Again ............................................................. 62

5.2 La Mettrie and Diderot: Aporias of Materialist Hedonism ............... 65

5.3 From the Libertine to the Laughing Philosopher:

A Possible Ethics? ..................................................................... 69

5.4 Materialism as an Ontology of Relations....................................... 73

5.5 Conclusion: On the Possibility (and Difficulty) of an Enlightenment Materialist Ethics.......................................... 74

References................................................................................ $\quad 76$

6 Naturalization, Localization: A Remark on Brains and the Posterity of the Enlightenment .............................................. 79

6.1 The Naturalization of the Soul ....................................................... 80

6.2 Localizing Mental Functions........................................................ 83

References........................................................................ 84

7 Materialism in Australia: The Identity Theory in Retrospect............. 87

7.1 Introduction ............................................................................... 87

7.2 The Early Genesis of the Theory: The Vienna

7.3 The Power of Reduction..................................................................... 91

7.4 The Identity Theory: Place, Smart and Armstrong ......................... 93

7.5 Reflections on the IT ............................................................ 99

7.5.1 With What Does the IT Begin? .......................................... 99

7.5.2 The IT as a Logical Theory ............................................. 101

7.6 A Challenge to any Materialism: Functionalism ........................... 101

7.7 Conclusion................................................................................ 104

References............................................................................ 106

8 Phantom Limbs and the First-Person Perspective:

An Embodied-Materialist Response ............................................... 109

8.1 Introduction ............................................................................ 109

8.2 First-Person Privilege? ................................................................... 111

8.3 An Embodied-Materialist Response ........................................ 113

8.3.1 Problems with the First Person ..................................... 114

8.3.2 Embodying Interiority ............................................... 115

8.4 De-Ontologizing the Brain ............................................................ 117

8.5 Conclusion................................................................................. 121

References............................................................................. 121 
9 Conclusion .................................................................................... 125

9.1 General Remarks ...................................................................... 125

9.2 Materialism and the Sciences....................................................... 127

9.3 Physicalism and the End ..................................................... 128

References.......................................................................... 130



